\title{
EVALUATION OF HERBS AS POTENTIAL DRUGS/MEDICINES
}

\author{
J.A. Odhiambo*¹, C.W. Lukhoba ${ }^{1}$, S.F. Dossaji ${ }^{1}$ \\ ${ }^{1}$ School of Biological Sciences, University of Nairobi P.O BOX 30197-00100, Nairobi, Kenya \\ *Email: judyodhis2003@yahoo.co.uk
}

\begin{abstract}
Herbal drugs have been used since ancient times as medicines for the treatment of a wide range of diseases, for both human and livestock. A study conducted in the Lake Victoria Basin Kenya revealed vast knowledge and reliance on traditional medicine as a source of healthcare. The study documented 34 medicinal plant species distributed among 21 botanical families and 34 genera, used in the management of human ailments. The highest numbers of species were from the families Asteraceae and Leguminosae. The most commonly harvested plant parts were leaves (46.51\%) and roots (34.88\%). The most common growth forms utilised were herbs $(40.54 \%)$ followed by shrubs $(27.03 \%)$. The major methods of herbal drug preparation were concoction (31.03\%) and decoction (24.14\%) administered mainly through oral and dermal routes, (64.29\%) and (32.14\%) respectively. The use of herbal drugs as mixtures was reported to be a common practice by the herbal practitioners; $57.14 \%$ of the preparations were dispensed as mixtures while $42.86 \%$ of the preparations composed of single plants. A rich knowledge of medicinal plants was recognized and phytochemical and bioactivity analyses of these herbal plants are recommended to determine their safety and efficacy.
\end{abstract}

Key words: Indigenous knowledge, health care, ethnomedicine

\section{Introduction}

Like any other developing and least developed nations, traditional medicine remains a primary health resource to a large population especially in the rural areas in Kenya. To most of them, the modern healthcare services are inaccessible and unaffordable (Yineger et al., 2008). The Kenyan Lake Victoria Basin is among the most densely populated areas in the country, known to have the highest poverty levels, with $41 \%$ of the population earning less than one dollar per day (SIDA, 2005). In addition, Kisumu, the largest administrative center in the Lake Victoria basin of Kenya, is ranked the poorest city in Kenya with $48 \%$ of its inhabitants living below the poverty line and associated with high HIV/AIDS prevalence (UN-HABITAT 2005; East African Community Secretariat, 2004). The population is also at risk of major infectious water-borne diseases (e.g cholera, typhoid,) vector borne diseases (e,g malaria, schistosomiasis) and sexually transmitted diseases ( e.g gonorhoea, syphilis ).Based on the mentioned challenges (G.o.K, 2007; AMREF, 2008), the majority of people in this region are dependent on traditional medicines mainly from plant origins, to manage various ailments they face in their day to day lives. Natural products derived from medicinal plants have proven to be an abundant source of biologically active compounds, many of which have been the basis for the development of new lead chemicals for pharmaceuticals (Palombo, 2006). This study was conducted with the aim of documenting the indigenous knowledge on the use of ethnomedicinal plants species by traditional healers within the Lake Victoria Basin, Kenya.

\section{Materials and methods \\ Collection of ethnomedicinal data}

Ethnomedicinal data was collected in September 2007 from Kisumu, Siaya, (Nyanza province) Bungoma, Busia, (Western province) and Kitale, Eldoret (Rift Valley province). Traditional healers who are also officials in the National Council of Association for Alternative, Complementary Medicine and Research were used to identify and register traditional practitioners residing in and around these sites. The ethnomedicinal data were based on structured interviews and questionnaires that sought answers to questions about the human ailments treated, local names of plant species, plant parts used, methods of preparation, and administration routes. In some cases, the interviews were facilitated by translators who were well conversant with the local languages. This was done having first obtained verbal informed consent from each traditional healer. The plant specimens from the traditional healers were collected as herbarium voucher specimens. These were pressed, dried, identified and deposited at the University of Nairobi Herbarium (NAI). Identification of specimens was done using taxonomic keys (Agnew and Agnew, 1994; Beentje, 1994) and by comparison with authentic herbarium materials. 


\begin{tabular}{|c|c|c|c|c|c|c|c|}
\hline Scientific name & $\begin{array}{l}\text { Vernacular } \\
\text { (local) } \\
\text { name }\end{array}$ & Growthform & $\begin{array}{l}\text { Part } \\
\text { used }\end{array}$ & Single (S) & Ailment(s) & Preparation/application & $\begin{array}{c}\text { Route of } \\
\text { administration }\end{array}$ \\
\hline $\begin{array}{c}\text { Ageratum conyzoides L. } \\
\text { (Asteraceae) }\end{array}$ & $\begin{array}{l}\text { Namasambu } \\
\text { (Luhya) }\end{array}$ & Herb & Leaves & $\mathrm{S}$ & $\begin{array}{l}\text { Mouth sores, } \\
\text { tetanus, fresh } \\
\text { wounds }\end{array}$ & $\begin{array}{l}\text { Pounded and juice } \\
\text { applied }\end{array}$ & Dermal \\
\hline $\begin{array}{l}\text { Tithonia diversifolia (Hemsl.) } \\
\text { A. Gray (Compositae) }\end{array}$ & $\begin{array}{l}\text { Mbekurahisi } \\
\text { (Luhya) }\end{array}$ & Shrub & Leaves & $\mathrm{S}$ & Malaria & $\begin{array}{l}\text { Pounded fresh, soaked } \\
\text { in cold water and drunk }\end{array}$ & Oral \\
\hline $\begin{array}{l}\text { Vernonia lasiopus O.Hoffm } \\
\text { (Asteraceae) }\end{array}$ & Nambaa (Teso) & Herb & Roots & $\mathrm{S}$ & Typhoid & $\begin{array}{l}\text { Pounded fresh, boiled } \\
\text { and drunk. }\end{array}$ & Oral \\
\hline $\begin{array}{l}\text { Schkuria pinnata (Lam) Thell. } \\
\text { (Asteraceae) }\end{array}$ & $\begin{array}{l}\text { Nabuyeywe } \\
\text { (Teso) }\end{array}$ & Herb & Whole & $\mathrm{S}$ & Malaria, fever & $\begin{array}{l}\text { pounded fresh or boiled } \\
\text { and liquid drunk }\end{array}$ & Oral \\
\hline $\begin{array}{l}\text { Indigofera dendroides Jacq. } \\
\text { (Leguminosae) }\end{array}$ & $\begin{array}{c}\text { Kumukuyu } \\
\text { (Luhya) }\end{array}$ & Herb & Leaves & $\mathrm{S}$ & $\begin{array}{l}\text { Fungal } \\
\text { diseases, } \\
\text { (mashillingi) }\end{array}$ & $\begin{array}{c}\text { Pounded fresh and juice } \\
\text { applied }\end{array}$ & Dermal \\
\hline $\begin{array}{c}\text { Plectranthus prostatus Guerke } \\
\text { (Lamiaceae) }\end{array}$ & Ang’we (Luo) & Herb & whole & $\mathrm{S}$ & $\begin{array}{l}\text { Skin } \\
\text { problems }\end{array}$ & $\begin{array}{l}\text { Pounded, soaked in cold } \\
\text { water for drinking and } \\
\text { bathing. }\end{array}$ & $\begin{array}{l}\text { Oral } \\
\text { Dermal }\end{array}$ \\
\hline $\begin{array}{l}\text { Hyptis suaveolens (L.) Poit. } \\
\text { (Lamiaceae) }\end{array}$ & Egopiny (Teso) & Shrub & Leaves & $\mathrm{S}$ & $\begin{array}{l}\text { Skin, wounds, } \\
\text { fungal } \\
\text { infections. }\end{array}$ & $\begin{array}{l}\text { Pounded fresh, soaked in } \\
\text { water for bathing }\end{array}$ & Dermal \\
\hline $\begin{array}{l}\text { Harrisonia abyssinica Oliv. } \\
\text { (Simaroubaceae) }\end{array}$ & $\begin{array}{l}\text { Sibondwe } \\
\text { (Luhya) }\end{array}$ & Shrub & Roots & S & $\begin{array}{l}\text { Fungal, } \\
\text { ringworms }\end{array}$ & Boiled and drunk & Oral \\
\hline $\begin{array}{l}\text { Moringa sp. Adans. } \\
\text { (Moringaceae) }\end{array}$ & Moringa & Tree & Leaves & $\mathrm{S}$ & $\begin{array}{l}\text { Skin diseases, } \\
\text { ringworms, } \\
\text { scabies }\end{array}$ & $\begin{array}{c}\text { Dried, pounded and } \\
\text { powder mixed with } \\
\text { Vaseline and paste used }\end{array}$ & Dermal \\
\hline $\begin{array}{l}\text { Moringa sp. Adans. } \\
\text { (Moringaceae) }\end{array}$ & Moringa & Tree & Leaves & S & $\begin{array}{l}\text { Skin diseases, } \\
\text { ringworms } \\
\text {,itching }\end{array}$ & $\begin{array}{l}\text { Dried, pounded and } \\
\text { powder mixed with } \\
\text { Vaseline and paste used }\end{array}$ & Dermal \\
\hline $\begin{array}{l}\text { Mangifera indica L. } \\
\text { (Anarcadiaceae) }\end{array}$ & $\begin{array}{l}\text { Maembe } \\
\text { (Swahili) }\end{array}$ & Tree & Leaves & $\mathrm{S}$ & $\begin{array}{l}\text { T.B, stubborn } \\
\text { cough and } \\
\text { malaise }\end{array}$ & $\begin{array}{l}\text { Pounded fresh, soaked in } \\
\text { cold water and drunk }\end{array}$ & Oral \\
\hline $\begin{array}{l}\text { Securidaca longipedunculata } \\
\text { Fresen. (Polygonaceae) }\end{array}$ & Elele (Teso) & Tree & Roots & S & $\begin{array}{l}\text { Cough and } \\
\text { chest pains }\end{array}$ & $\begin{array}{l}\text { Pounded, dried, pinch of } \\
\text { powder added to } \\
\text { porridge and drunk }\end{array}$ & Oral \\
\hline $\begin{array}{c}\text { Carissa edulis (Forssk.) Vahl } \\
\text { (Apocynaceae) }\end{array}$ & Sirrhua (Luhya) & Shrub & Root & $\mathrm{S}$ & S.T.I & $\begin{array}{l}\text { Dried, pounded into } \\
\text { powder, soaked in water } \\
\text { and drunk }\end{array}$ & Oral \\
\hline Ricinus communis L. & Kuresiet & Shrub & Roots & $\mathrm{S}$ & Diarrhoea and & Boiled and drunk & Oral \\
\hline
\end{tabular}

doi: 10.4314/ajtcam.v8i5S.20 
Odhiambo et al., Afr J Tradit Complement Altern Med. (2011) 8(S):144-151

\begin{tabular}{|c|c|c|c|c|c|c|c|}
\hline (Euphorbiacea) & (Kalenjin) & & & & vomiting & & \\
\hline Ximenia caffra Sond. (Olacacea) & Kumutili (Luhya) & Tree & Root & $\mathrm{S}$ & $\begin{array}{l}\text { Ulcer, } \\
\text { wounds, } \\
\text { asthma }\end{array}$ & $\begin{array}{l}\text { Pounded fresh or dry } \\
\text { then applied in open } \\
\text { wounds. } \\
\text { Powder added to water } \\
\text { and drunk }\end{array}$ & $\begin{array}{c}\text { Dermal } \\
\text { Oral }\end{array}$ \\
\hline $\begin{array}{l}\text { Dichondra repens J.R. Forst \& } \\
\text { G. Forst. (Convulvulaceae) }\end{array}$ & $\begin{array}{l}\text { Nalulanda } \\
\text { (Luhya) }\end{array}$ & Herb & Leaves & $\mathrm{S}$ & $\begin{array}{l}\text { Skin wounds, } \\
\text { ringworms }\end{array}$ & $\begin{array}{l}\text { Pounded fresh with oil or } \\
\text { ghee, paste used }\end{array}$ & Dermal \\
\hline $\begin{array}{c}\text { Oxygonium sinuatum (Hochst. \& } \\
\text { Steud. Ex Meisn.)Dammer } \\
\text { (Polygonaceae) }\end{array}$ & $\begin{array}{l}\text { Nabikumba } \\
\text { (Luhya) }\end{array}$ & Herb & Leaves & $\mathrm{S}$ & Boils & $\begin{array}{c}\text { Pounded fresh, paste } \\
\text { used applied }\end{array}$ & Dermal \\
\hline $\begin{array}{l}\text { Gladiolus dalenii Van Geel. } \\
\text { (Iridaceae) }\end{array}$ & $\begin{array}{l}\text { Liandamuna } \\
\text { (Luhya) }\end{array}$ & Herb & Bulb & $\mathrm{S}$ & $\begin{array}{l}\text { Meningitis } \\
\text { malaria } \\
\text { diarrhoea }\end{array}$ & $\begin{array}{l}\text { Dried, pounded, sieved, } \\
\text { and sniffed to treat } \\
\text { meningitis. } \\
\text { A pinch of powder added } \\
\text { to water and drunk to } \\
\text { treat malaria and } \\
\text { diarrhoea. }\end{array}$ & $\begin{array}{c}\text { Nasal } \\
\text { Oral }\end{array}$ \\
\hline
\end{tabular}

doi: 10.4314/ajtcam.v8i5S.20 


\section{Results}

Malaria, Sexually Transmitted Diseases (STD), skin infections and typhoid were the top reported ailments handled by the traditional practitioners. Thirty four medicinal plant species distributed within twenty one botanical families were identified in the treatment of eighteen human ailments. Asteraceae had the highest number of species of medicinal value followed by Leguminosae then Lamiaceae, (Table 1 and 2). The ailments/complaints treated, plant and parts used, mode of preparation, route of administration, use as single or mixture and growth forms of the plants used have been summarized in Table 1 and 2 . It was noted that in most cases, herbalists prepare their herbal drugs by combining plant parts from several plants. Herbal drugs prepared from more than one plant (mixtures) made up 57.14\% while those from single plants made up 42.86\%. Herbs were the most represented growth forms (40.54\%) harvested for remedy preparation. These were followed by shrubs then trees $(27.03 \%$ and $24.32 \%$ respectively). Most medicinal plant species were harvested for their leaves (46.51\%) followed by roots (34.88\%) to prepare remedies. Bulbs and fruits (2.33\% respectively) were the least harvested. The most commonly prepared herbal drugs were concoction (31.03\%), decoction (24.14\%) and powdering (20.69\%). Many of these herbal drugs, particularly concoction and decoction, were made palatable by being incorporated into porridge, tea, honey, beer etc. Traditional ghee, oil, and Vaseline were reportedly used as additives and carriers for those drugs prepared as pastes. Prepared herbal remedies were mostly administered orally (64.29\%) and through dermal routes (32.14\%). Nasal administration made up a mere $3.57 \%$. Dosages of the remedial prescriptions were measured using water glasses, pinches, spoons, and cups.

\section{Discussion}

Traditional healers of Lake Victoria Basin were found to play a vital role in the primary healthcare of the local people as they constituted the main resource persons health problems in the area. This may be attributed to low financial capacity to access modern healthcare on one hand, and belief in the healers' capability to handle most of their health problems on the other hand. The plant family reported with the highest number of medicinal plant species was Asteraceae followed by Leguminosae and Lamiaceae. This trend is in agreement with the findings by Yineger et al., (2008) who reported Asteraceae and Lamiaceae as the first and third families, respectively, with the highest number of medicinal plant species, but is in contrary to those of Yineger \& Yewhalaw (2007) who reported the most representive families as Leguminosae, Acanthaceae and Curcubitaceae successively. The discrepancy may be due to ecological, geographical and environmental factors (Runyoro et al., 2006) which favour growth of some plants and not others.

There was evidence of high secrecy in the medicinal plant usage with a number of healers not ready to reveal full details of their knowledge about the medicinal plants to us. Many reported not having transferred the knowledge to the subsequent generation. The secrecy surrounding the ethnomedicinal knowledge among the Traditional healers could be attributed to the fact that they derive income from the services they provide. This observation is in agreement with findings by Yineger et al., (2008) and Yineger \& Yewhalaw, (2007) who noted that apart from income, traditional healers get in-kind compensation and would therefore like the value of the indigenous knowledge maintained. Ng'etich, (2005) reported that some traditional healers regard the knowledge as personal property, Kokwaro (1993) reported that in some cases oaths were taken during passing of the information so that it is not revealed to any one else.

The degree of agreement by the healers in dealing with ailments such as malaria using Tithonia diversifolia (Asteraceae )and Schkuria pinnata,(Asteraceae) ; sexually transmitted infections using Albizia coriaria (Leguminosae) and Harrisonia abyssinica (Simaroubaceae), and ringworms using Moringa sp. (Moringaceae) could give high validity to these species in the treatment of the mentioned ailments. The agreement could also be due to the effective results on the plants' usage from past experience, the species availability and existence of these ailments as the most encountered ones.

The use of traditional medicinal plants as mixtures by traditional healers to manage one or more human ailments was reported. In fact the majority of the ethnomedicinal plants collected were used as mixtures. This could be due to the additive effects that they may have during treatment (Bussman and Sharon, 2006; Igoli et al., 2002). The traditional healer may not be sure of the specific ailment the patient could be suffering from and therefore gives a mixture of several herbal medicinal preparations as a remedy to potential ailments judging from the patients' condition. Another reason could be due to the synergistic action of the different preparations expected by the practitioner. Use of traditional herbal remedies as mixtures of different herbs has also been reported in Chinese traditional medicine by Xiao (1983). Some of the plants in the mixture could however be acting as antipyretics, immune stimulants to relieve the symptoms of the disease rather than having direct activity as reported by Philipson et al., (1993), and some could also be nutritive. However, Xiao (1983) explained that determination of the pharmacological effects and isolation of active principles from the herbal mixtures is much more difficult than in the case of single medicinal plants, owing to the interaction of various constituents. In this study, it was also observed that most of the medicinal plant species were used to treat more than one ailment. This could be due to the availability of the herbal plant or its effectiveness from past experience in the treatment of various ailments, an observation also noted by Lukhoba et al., (2006), Boer et al., (2005) Okemo et al., (2003) and Kokwaro, (1993). 
Table 2: Ethnomedicinal data collected from Lake Victoria, Basin Kenya with herbal preparations consisting of more than one plant

\begin{tabular}{|c|c|c|c|c|c|c|c|}
\hline Mixture (M) & Scientific name & $\begin{array}{c}\text { Vernacular } \\
\text { name }\end{array}$ & $\begin{array}{l}\text { Growth } \\
\text { form }\end{array}$ & Part used & $\begin{array}{l}\text { Ailment } \\
\text { (s) }\end{array}$ & $\begin{array}{c}\text { Preparation/applic } \\
\text { ation }\end{array}$ & $\begin{array}{c}\text { Route of } \\
\text { administration }\end{array}$ \\
\hline \multirow[t]{3}{*}{$\mathrm{M}_{1}$} & $\begin{array}{l}\text { Senna occidentalis (L.) } \\
\text { Link. } \\
\text { (Leguminosae) }\end{array}$ & $\begin{array}{c}\text { Enyeribebe, } \\
\text { Ekayeywet (Teso) }\end{array}$ & Tree & Leaves & \multirow[t]{3}{*}{$\begin{array}{l}\text { Malaria, } \\
\text { typhoid }\end{array}$} & \multirow[t]{3}{*}{$\begin{array}{l}\text { Pounded together, } \\
\text { burned, ash soaked } \\
\text { in water and drunk. }\end{array}$} & \multirow[t]{3}{*}{ Oral } \\
\hline & $\begin{array}{l}\text { Tithonia diversifolia } \\
\text { (Hemsl.) A. Gray } \\
\text { (Asteraceae) }\end{array}$ & Tithonia & Shrub & Leaves & & & \\
\hline & Aloe sp. L. (Aloaceae) & Ichichiku (Teso) & Herb & Leaves & & & \\
\hline \multirow[t]{3}{*}{$\mathrm{M}_{2}$} & $\begin{array}{l}\text { Tagetes minuta } \mathrm{L} . \\
\text { (Asteraceae) }\end{array}$ & Ngukwe (Teso) & Herb & Leaves & \multirow[t]{3}{*}{$\begin{array}{l}\text { Malaria, } \\
\text { meningitis }\end{array}$} & \multirow[t]{3}{*}{$\begin{array}{l}\text { Pounded fresh, } \\
\text { boiled and drunk }\end{array}$} & \multirow[t]{3}{*}{ Oral } \\
\hline & $\begin{array}{l}\text { Schkuria pinnata } \\
\text { (Lam) Thell (Asteraceae) }\end{array}$ & Nabuyeywe (Teso) & Herb & Leaves & & & \\
\hline & $\begin{array}{l}\text { Conyza sumatrensis } \\
\text { (Retz.)E. } \\
\text { (Asteraceae) }\end{array}$ & Nalusambu (Teso) & Herb & Leaves & & & \\
\hline \multirow[t]{5}{*}{$\mathrm{M}_{3}$} & $\begin{array}{l}\text { Entada abyssinica Steud. } \\
\text { Ex A. Rich. (Leguminosae) }\end{array}$ & $\begin{array}{l}\text { Kumukokwe } \\
\text { (Teso) }\end{array}$ & Tree & Bark & \multirow[t]{5}{*}{ S.T.D } & \multirow{5}{*}{$\begin{array}{l}\text { Dried and pounded } \\
\text { together into } \\
\text { powder, added to } \\
\text { busaa, porridge, or } \\
\text { hot water and drunk }\end{array}$} & \multirow[t]{5}{*}{ Oral } \\
\hline & $\begin{array}{l}\text { Harrisonia abyssinica } \\
\text { Oliv. (Simaroubaceae) }\end{array}$ & Sibondwe (Teso) & Shrub & Roots & & & \\
\hline & $\begin{array}{l}\text { Albizia coriaria Welw.ex } \\
\text { Oliv. (Leguminosae) }\end{array}$ & Kumupeli(Teso) & Tree & Bark & & & \\
\hline & $\begin{array}{l}\text { Carissa edulis (Forssk.) } \\
\text { Vahl (Apocynaceae) }\end{array}$ & $\begin{array}{c}\text { Kumurhwa } \\
\text { (Teso) }\end{array}$ & Shrub & Leaves & & & \\
\hline & $\begin{array}{l}\text { Acacia hockii De Wild. } \\
\text { (Leguminosae) }\end{array}$ & $\begin{array}{l}\text { Kumunyenya } \\
\text { (Teso) }\end{array}$ & Tree & Back & & & \\
\hline \multirow[t]{4}{*}{$\mathrm{M}_{4}$} & $\begin{array}{l}\text { Hippocratea sp. L. } \\
\text { (Celastraceae) }\end{array}$ & Ekuo (Teso) & Shrub & Root & \multirow[t]{4}{*}{ S.T.D } & \multirow[t]{4}{*}{$\begin{array}{l}\text { Boiled together } \\
\text { fresh and drunk }\end{array}$} & \multirow[t]{4}{*}{ Oral } \\
\hline & $\begin{array}{l}\text { Erythrina excelsa Benth. } \\
\text { (Leguminosae) }\end{array}$ & Ekayeywet (Teso) & Tree & Root & & & \\
\hline & $\begin{array}{l}\text { Combretum molle R.Br ex } \\
\text { G. Don (Combretaceae) }\end{array}$ & Ekuluny (Teso) & Tree & Root & & & \\
\hline & $\begin{array}{l}\text { Turraea robusta Guerke. } \\
\text { (Meliaceae) }\end{array}$ & Etikwa (Teso) & Shrub & Root & & & \\
\hline
\end{tabular}

doi: 10.4314/ajtcam.v8i5S.20 
Odhiambo et al., Afr J Tradit Complement Altern Med. (2011) 8(S):144-151

\begin{tabular}{|c|c|c|c|c|c|c|c|}
\hline & & & & & & & \\
\hline \multirow[t]{2}{*}{$\mathrm{M}_{5}$} & $\begin{array}{l}\text { Harrissonia abyssinica } \\
\text { Oliv. (Simaroubaceae) }\end{array}$ & Mugende (Teso) & Shrub & Root & \multirow[t]{2}{*}{ S.T.D } & $\begin{array}{c}\text { Pounded fresh, } \\
\text { soaked in water and } \\
\text { drunk }\end{array}$ & \multirow[t]{2}{*}{ Oral } \\
\hline & $\begin{array}{l}\text { Albizia coriara } \\
\text { Welw.ex Oliv. } \\
\text { (Leguminosae) }\end{array}$ & Kumupeli (Teso) & Tree & Root & & & \\
\hline \multirow[t]{2}{*}{$\mathrm{M}_{6}$} & $\begin{array}{l}\text { Hoslundia opposita Vahl. } \\
\text { (Lamiaceae) }\end{array}$ & Upwaka (Teso) & Shrub & Leaves & \multirow[t]{2}{*}{ Asthma } & $\begin{array}{c}\text { Mixture of fresh } \\
\text { leaves pounded, and } \\
\text { soaked in hot water } \\
\text { then drunk }\end{array}$ & \multirow[t]{2}{*}{ Oral } \\
\hline & $\begin{array}{l}\text { Pavetta crassipes K.Schum } \\
\text { (Rubiaceae) }\end{array}$ & Ochumbi (Teso) & Shrub & Leaves & & & \\
\hline \multirow[t]{5}{*}{$\mathrm{M}_{7}$} & $\begin{array}{l}\text { Toddalia asiatica (L.) Lam } \\
\text { (Rutaceae) }\end{array}$ & Pili (Kalenjin) & Liane/Shrub & Root & \multirow[t]{5}{*}{ Malaria } & \multirow{5}{*}{$\begin{array}{l}\text { All the plants' } \\
\text { portion taken in } \\
\text { equal proportions, } \\
\text { cut into pieces, put } \\
\text { together boiled and } \\
\text { drunk. }\end{array}$} & \multirow[t]{5}{*}{ Oral } \\
\hline & $\begin{array}{l}\text { Podocarpous falcatus } \\
\text { (Thunb)R. Br.ex Mirb. } \\
\text { (Podocarpaceae) }\end{array}$ & Benii (Kalenjin) & Tree & Bark & & & \\
\hline & $\begin{array}{l}\text { Aloe sp. L } \\
\text { (Aloaceae) }\end{array}$ & Tengebi (Kalenjin) & Herb & Succulent leaves & & & \\
\hline & $\begin{array}{l}\text { Rhamnus staddo A. Rich. } \\
\text { (Rhamnaceae) }\end{array}$ & Blakii (Kalenjin) & Shrub & Root & & & \\
\hline & $\begin{array}{l}\text { Momordica foetida } \\
\text { Schumach. (Cucurbitaceae) }\end{array}$ & Tendere (Kalenjin) & Herb & $\begin{array}{l}\text { Shoot including } \\
\text { fruits }\end{array}$ & & & \\
\hline
\end{tabular}

Legend: M; Mixture (different plants used together in a single preparation)

$\mathbf{M}_{1}-\mathbf{M}_{7}$; Different plants used to prepare the different mixtures 
Results of this ethnomedicinal study revealed that traditional healers used non plant additives such as the animal ghee, Vaseline, oil during preparation. This could be attributed to the increase of potency of the medicinal plant as reported by Otieno et al., (2007) in Tanzania who found that crude mineral Kadosero supplemented to other plants extracts by the herbal practitioners showed increased activity of the herbal medicine. Olembo et al., (1995) also reported a similar scenario where Dichondria repens (Convolvulaceae) leaves were crushed and mixed with oil to treat dermatological ailments. The same plant on its own showed no activity when tested against a dermatological fungus by Kariba (2000).

This study reported herbs as the most used growth form used for remedy preparation, the second and third being shrubs and trees respectively. High usage of herbs may be attributed to the fact that they tend to grow in nearly all climatic conditions, have fast growth and tend to be available in conspicuous places like crop farms, disturbed areas, along the roadsides and along fences where they can be easily accessed . Leaves were the most cited plant parts used by the healers for the preparation of medicine followed by the roots. This popular usage of leaves may be attributed to the fact that they are aerial and easily harvested compared to the roots and the fact that they are always present in a plants' life in contrast to fruits and bulbs which occur only during certain seasons. This finding is in line with the results of other ethnomedicinal studies such as those by Yineger et al., (2008) and Yineger \& Yewhalaw, (2007). Most of the ethnomedicinal plant species were reported to be processed through concoction, decoction, powdering and administered mainly through oral and dermal routes, however the dosages lacked precision as they were given in cups, water glasses or in a basin. This report was found to be in agreement with that of Erasto et al ., (2008) , Boer et al., (2005) , Kokwaro, (1993) and Yineger et al., (2008) who in addition mentioned that there could arise cases of over dose which could cause serious health problems due to toxicity of some species. Our report on remedy preparation is however in contrary to the findings by Yineger \& Yewhalaw, (2007) in Ethiopia who reported the principal methods of remedy preparation as crushing and squeezing. Nature of ailments treated and healers' past experience on results may have contributed to the observed difference.

\section{Conclusion and Recommendation}

A large number of the collected medicinal plants were wild. A rich knowledge on medicinal plant use was recognized. However the healers be made aware of need for cultivation, field management and sustainable use of these medicinal plants. It is also recommended that Phytochemical and bioactivity studies should be conducted on the reported medicinal plants species to determine the efficacy for possible drug development.

\section{Acknowledgements}

The authors wish to thank the InterUniversity Council of East Africa (IUCEA) for sponsoring this research. Traditional healers of Lake Victoria Basin are genuinely acknowledged for their hospitality. Technical assistance by Mr. Simon Mathenge is greatly appreciated, and the University of Nairobi, School of Biological sciences for letting us use the available facilities.

\section{References}

1. Agnew, A.D.Q., Agnew, S., (1994). Upland Kenya wild flowers, $2^{\text {nd }}$ Ed. East Africa Natural History Society. African Medical and Research Foundation, (2008). AMREF.

2. Beentje, H.J., (1994). Kenya trees, shrubs and Lianas. National Museums of Kenya. Nairobi.

3. Boer, J.H., Kool, A., Mziray, W.R., Herdberg I., Levenfors J.J., (2005). Antifungal and antibacterial activity of some herbal remedies from Tanzania. J. Ethnopharmacol. 96: 461-469.

4. Bussmann, R.W., and Sharon, D.,(2006) .Traditional plant use in Northern Peru: Tracking two thousand years of health culture. J. Ethnobiology and Ethnomedicine.2: 47.

5. East African Community (2004). The vision and strategy Framework for management and Development of Lake Victoria, Basin . East African Community

6. Erasto, P., Adebola, P. O., Grierson, D. S., Afolayan, A. J., (2005). An ethnobotanical study of plants used for the treatment of diabetes in the Eastern Cape Province, South Africa. A, J. Biotechnol. 4 (12), 1458-1460.

7. Government of Kenya, (2007). Kenya Aids Indicator Survey Results.Government of.Kenya.

8. Igoli, J.O., Tor-Anyiin, TA., Usman, S.S., Oluma, H.O.A., Igoli, NP., (2002). Folk medicines of the lower Benue valley of Nigeria. In: Recent Progress in Medicinal Plants, Vol.7 Ethnomedicine and Pharmacognosy II, (Eds. V.K Singh, J.N. Govil, S. Hashmi and G. Singh), Sci. Tech. Pub. , USA. 327-338.

9. Kariba M. R., (2000). Antifungal activity of extracts from selected Kenyan medicinal plants. Ph.D thesis, University of Nairobi, Nairobi, Kenya.

10.Kokwaro J.O., (1993). Medicinal plants of East Africa. East Africa $2^{\text {nd }}$.Ed. Literature Bureau, Nairobi.

\section{doi: 10.4314/ajtcam.v8i5S.20}


11.Lukhoba C.W., Simmonds M.S.J., Paton A.J.,( 2006). Plectranthus: A review of ethnobotanical uses. J. Ethnopharmacol. 103 (1):1-24.

12.Ng'etich K.A., (2005). Indegenious Knowledge, Alternative medicine and Interlectual Property Rights concerns Kenya. Paper presented in the $11^{\text {th }}$ General Assembly Maputo, Mozambique, 6-10.

13.Okemo, P.O., Bais, P.H.,Vivanco, M.J., (2003). In vitro activities of Maesa lanceolata extracts against fungal plant pathogens. Fitoterapia $\mathbf{7 4}:$ 312-316.

14.Olembo, N.K., Fedha, S.S., Ngaira, E.S., (1995). Medicinal and Agricultural plants of Ikolomani Division, Kakamega District. Signal press L.t.d Nairobi.

16.Otieno, J.N., Hosea, K.M.M., Lyaruu, H.V. (2007). The effect of a local mineral Kadosero towards the antimicrobial activity of medicinal plant's extract: case of Lake Victoria, Basin, Tarime Tanzania. Afr J. Trad. Complement Altern Med. 4, (1): 16.

17.Palombo, E.A (2006). Phytochemicals from Traditional Medicinal Plants used in the Treatment of Diarrhoea: Modes of Action and Effects on Intestinal Function. Phytotherapy Research 20, 717-724.

18.Phillipson, J.D., Wright, C.W., Kirby, G.C., Warhurst, D.C., (1993).Tropical Plants as sources of antiprotozoal agents. Recent Advances in Phytochemistry, 27: 1-40.

19.Runyoro D., Matee M., Ngassapa O., Joseph C., Mbwambo Z.,(2006).Screening of Tanzanian medicinal plants for anticandida activity. BMC Complementary and Alternative Medicines 30;6 (1):1472-6882.

20.Swedish International Development Cooperation Agency, SIDA, (2005). United Nations Human Settlements Programme, Lake Victoria (2005). A review workshop on managing HIV/AIDS pandemic at the Local level in Africa. UN- HABITAT.

21.Xiao P.G., (1983). Medicinal plants: the Chinese approach. J. Ethnopharmacol, 7:95

22. Yineger, H., Kelbessa , E., Bekele, T., Lulekal, E., (2008). Plants used in traditional management of human ailments at Bale Mountains National Park, Southeastern Ethiopia. Journal of medicinal plant research. 2 (6,) 132-153.

23.Yineger, H., and Yewhalaw, D., (2007). Traditional medicinal plants knowledge and use by Ioc Sekoru District, Jimma Zone, Southwestern Ethiopia. J. Ethnobiology and Ethnomedicine 3: 24. 